\title{
REMAKING HISTORY: THE PEDAGOGIC DEVICE AND SHIFTING DISCOURSES IN THE SOUTH AFRICAN SCHOOL HISTORY CURRICULUM
}

\author{
DOI: http://dx.doi.org/10.17159/2223-0386/2020/n23a1 \\ Carol Bertram \\ University of KwaZulu-Natal \\ Pietermaritzburg, South Africa \\ BertramC@ukzn.ac.za \\ ORCID No: orcid.org/0000-0002-2961-5645
}

\section{Abstract}

This article uses Bernstein's pedagogic device as a framing heuristic to trace the shifts in the South African school history curriculum from 1995 - 2019. The article focuses on how the instructional and regulative discourses have changed over the past 25 years. The instructional discourse refers to the selection, sequencing, pacing and assessment of knowledge, while the regulative discourse refers to the rules that create social order. I map the curriculum shifts onto the broader policy discourses, such as the competence framework of outcomes-based education (which informed the South African curriculum from 1997 to 2011), the performativity and accountability discourse which emerged after 2012 and the discourses of decolonisation that strengthened after 2015. This article aims to tell the story of how the history curriculum reforms reflect the broader regulative discourses and to show the relationships between the official and pedagogical recontextualising fields. The story is a detailed case study of how curriculum design is influenced by selection logics that are both internal and external to the discipline of history, which reflects curriculummaking as a process fraught with tensions and fractures.

Keywords: School history curriculum; Pedagogic device; Policy discourses; South Africa.

\section{Introduction}

Bernstein's pedagogic device provides a set of general principles which inform how knowledge is selected into official curricula and how this knowledge is transformed into pedagogic communication. I use the pedagogic device here to show how the broader educational discourses in South Africa have influenced the official school history curriculum. The aim of this article is to interrogate the various history curriculum reforms between 1994 and 2019 and create a narrative of the interactions, tensions 
and contradictions that have played out between the general regulative discourses and the instructional discourses of the history curriculum over the past 25 years.

I draw on official curriculum policy, Ministerial task team reports, existing accounts and studies of curriculum reform to show how the nature of substantive and procedural history knowledge has shifted in the various official history curricula since 1990, as well as how the purpose of, and justification for teaching school history has changed. I map the curriculum shifts onto the broader policy discourses, such as the competence framework of outcomes-based education (which informed the South African curriculum from 1997 to 2011), the performativity and accountability discourse which emerged from 2012 and the discourses of decolonization that strengthened after 2015. This article aims to tell the story of how the history curriculum reforms reflect the broader regulative discourses and to show the relationships between the official and pedagogical recontextualising fields. The story is a detailed case study of how curriculum design is influenced by selection logics that are both the internal and external to the discipline of history, which reflects curriculummaking as a process fraught with tensions and fractures.

The article follows a chronological narrative of the various history curriculum reforms in South Africa from 1990 until the present. The post-apartheid reforms in the South African curriculum from the radical, outcomes-based Curriculum 2005 to the more structured Curriculum and Assessment Policy Statements (CAPS) in 2011 are well-rehearsed both from a general perspective (Hoadley 2018; Chisholm 2005), as well as from the perspective of the history curriculum (Wassermann 2017; Chisholm 2015). I use the pedagogic device as a theory and a heuristic device to interrogate how different levels in the education system engaged to create a new curriculum document. The landscape that I survey is broad, hence I present 'snapshots' of five curriculum reform moments, which cannot provide detail at every level of the device.

\section{Theoretical framing}

The pedagogic device is an attempt to describe the general principles which underlie the transformation of knowledge into pedagogic communication (Bernstein, 1996). Bernstein uses the term to refer to systemic and institutionalized ways in which knowledge is recontextualised from the field of knowledge production into the school system and its distribution 
and evaluation within the schooling system (Jacklin, 2004). Singh (2002) describes the pedagogic device as an ensemble of rules or procedures described by Bernstein which provide a model for analysing the processes by which expert knowledge is converted into classroom talk and curricula. The process of recontextualising entails the principle of de-location (that is selecting a discourse or part of a discourse from the field of production where new knowledge is constructed) and a principle of re-location of that discourse as a discourse within the recontextualising field (Bernstein 2000: 113). In this process of de- and re-location, the original discourse undergoes an ideological transformation. This process produces dilemmas and tensions (Lamnias 2002).

Table 1: The arena of the pedagogic device

\begin{tabular}{|c|c|c|c|}
\hline Field of practice & $\begin{array}{l}\text { Production } \\
\text { (where knowledge } \\
\text { is produced) }\end{array}$ & $\begin{array}{l}\text { Recontextualisation } \\
\text { (where knowledge } \\
\text { is selected and } \\
\text { sequenced into } \\
\text { curriculum } \\
\text { documents or } \\
\text { textbooks) }\end{array}$ & $\begin{array}{l}\text { Reproduction (where } \\
\text { teachers transmit and } \\
\text { evaluate knowledge) }\end{array}$ \\
\hline Form of regulation & Distributive rules & $\begin{array}{l}\text { Recontextualising } \\
\text { rules }\end{array}$ & Evaluative rules \\
\hline $\begin{array}{l}\text { Kinds of symbolic } \\
\text { structure }\end{array}$ & $\begin{array}{l}\text { Knowledge } \\
\text { structure }\end{array}$ & Curriculum & $\begin{array}{l}\text { Pedagogy and } \\
\text { evaluation }\end{array}$ \\
\hline Typical agents & $\begin{array}{l}\text { Academics, } \\
\text { professional } \\
\text { historians }\end{array}$ & $\begin{array}{l}\text { Official } \\
\text { Recontextualising } \\
\text { Field }(O R F) \text { : } \\
\text { Curriculum } \\
\text { writers, Pedagogic } \\
\text { Recontextualising } \\
\text { Field }(P R F) \text { : } \\
\text { teacher educators, } \\
\text { textbook writers }\end{array}$ & Teachers \\
\hline Typical sites & $\begin{array}{l}\text { Research papers, } \\
\text { conferences, } \\
\text { laboratories }\end{array}$ & $\begin{array}{l}\text { Curriculum policy, } \\
\text { textbooks, learning } \\
\text { aids }\end{array}$ & $\begin{array}{l}\text { Classrooms and } \\
\text { examinations } \\
\text { (assessment tasks) }\end{array}$ \\
\hline
\end{tabular}

Source: Adapted from Maton \& Muller, 2007:18.

The device consists of three rules, the distributive, recontextualising and evaluative rules which give rise to three respective fields of practice (see Table 1). There are agents in these fields who seek domination through their positions/ practices (Bernstein \& Solomon, 1999). These arenas 
are the field of production (where knowledge is produced), the field of recontextualisation (where knowledge is selected and sequenced into curriculum documents and textbooks) and the field of reproduction (classrooms where teachers transmit and evaluate the selected knowledge). The pedagogic device is a site of struggle, for the "group who appropriates the device has access to a ruler and distributer of consciousness, identity and desire" (Bernstein \& Solomon, 1999: 269). Symbolic control is materialized through the pedagogic device. There are a range of agencies which make up the fields of the pedagogic device, and these fields are social spaces of conflict and competition.

Distributive rules specialize forms of knowledge, forms of consciousness and forms of practice to social groups. They establish who gets access to what knowledge, that is, to which privileged and specialised ways of classifying, ordering, thinking, speaking and behaving (Ensor, 2004). The field of production is the field where knowledge is created by researchers in universities and other research institutions.

Recontextualising rules constitute specific pedagogic discourses. Pedagogic discourse is seen as a grammar which underlies the three fields of the pedagogic device (Bernstein, 2000). Pedagogic discourse is a rule that embeds two discourses: a discourse of knowledge and skills of various kinds and their relations to each other (called the instructional discourse), and rules that create social order (called the regulative discourse). Bernstein (2000) notes that the rules of the instructional discourse refer to the selection, sequence, pacing and evaluative criteria of the knowledge.

Actors in the recontextualising field make choices as to what kind of knowledge is selected for the school curriculum, how it is sequenced, paced and evaluated. The recontextualising field is key in creating the fundamental autonomy of education. Bernstein distinguishes between an official recontextualising field (ORF) that is created and dominated by the state and its selected ministries and agents, and a pedagogic recontextualising field (PRF). The PRF is made up of teacher educators in university departments of education, specialised journals, private research foundations and textbook writers. If the actors in the PRF can have an effect on pedagogic discourse independently of the ORF, then there is some autonomy and contestation over pedagogic discourse and its practices. The relationship between the $\mathrm{ORF}$ and PRF can vary within the same country over time. Sometimes the PRF can become a space where agents can develop curricula and pedagogy 
with some degree of independence of the ORF, in other cases the ORF significantly constrains the ability of the PRF to function (Ensor, 2004).

The third field of practice is the field of reproduction, where teachers transmit and evaluate knowledge. It is in this field that teachers can enact the relative autonomy of education, depending on the extent to which teachers can interpret and adapt the official curriculum. Teachers'pedagogic practice is informed by both instructional and regulative discourses that are relayed in the official curriculum and textbooks, as well as by their own experiences of learning and beliefs about the purposes of teaching history.

Regarding the question of how the instructional pedagogic discourse principle relates to the specific subject of school history, I have argued that the distinction between substantive and procedural knowledge in the discipline of history (Lee \& Ashby 2000; Schwab 1978; Lee 2004; Lévesque 2008) is a useful analytic tool for curriculum analysis (Bertram 2009, 2012). Substantive history knowledge or first order concepts encompass an understanding of space, place and time. This means knowing what happened, why and when; knowing the propositions of history which are constructed by historians using their procedural investigations. It includes knowledge of the key concepts and periods which make up the content of history - periods such as the Ming Dynasty, Industrial Revolution, the Cold War and concepts such as communism, capitalism, colonialism, feudalism and monarchy (Bertram, 2016). Procedural knowledge, or second order concepts (Lee \& Ashby, 2000), are the organising ideas which give meaning and structure to events in history such as chronology, change and evidence that inform our understanding of the discipline of history. I will make use of these two concepts in my analysis of the curriculum shifts.

The regulative aspect of pedagogic discourse is reflected in the way that a national curriculum understands the purpose of school history. One approach to school history promotes knowledge of national history and national values in the interests of preserving collective memory and fostering national identity, while another approach is based on a disciplinary focus supported by historical thinking, where the content is not dominated by the nation but has become diversified and globalised (Guyver, 2013). A national identity discourse is similar to Lévesque's (2008) concept of Memory-history, which he describes as a "factual" tradition that focuses on commemoration, memory and heritage, where history can be known by remembering it. Memory-history is often used to 
support a particular version of a national history. Wertsch's (2002) term for this category is collective history, which is the usable past created by those in positions of power to serve particular political and identity needs. In contrast to this, Disciplinary-history is about learning to think historically using specific disciplinary processes, such as "a lengthy immersion in the primary sources, a deliberate shedding of present-day assumptions and a rare degree of empathy and imagination" (Tosh, 2006:12). It acknowledges a range of different perspectives, recognises ambiguity and separates the past from the present (Wertsch, 2002).

The study will describe how the instructional discourses (that is, what knowledge is selected and how it is organized) have shifted from one reform to the next, as well as how the general regulative or moral discourses have influenced these knowledge selections. I understand discourse to mean the ideas and ways of thinking that circumscribe what can be spoken or thought, by whom, when and on what authority (Ball, 2006).

\section{Methodology}

The empirical evidence is gathered from the official curriculum documents and government reports from each wave of reform, as well as existing studies in the field. For the General Education and Training band (GET), the official documents are Curriculum 2005 (Department of Education 1997), the NCS Grade 0 -9 (Department of Education, 2002) and the CAPS Social Science Grade 4 - 9 (Department of Basic Education, 2011b). For the Further Education and Training (FET) ${ }^{1}$ phase, the official documents are the first post- apartheid curriculum Interim Core Syllabus (ICS) Std 8 - 10 (1996), the NCS Grade 10 - 12 (2003) and the CAPS History Grade 10 - 12 (Department of Basic Education, 2011a). In addition, I engage with reports of the various committees established by the Minister of Education to review the curriculum such as the Curriculum 2005 review (Department of Education, 2000b), the History and Archaeological Panel (Department of Education, 2000a), the review of the implementation of the NCS (Department of Education, 2009) and the History Ministerial Task Team report (Ndlovu et al., 2018). Further reference will be made to other research and studies that have been published at the time of the curriculum reforms.

1 The South African schooling system comprises the General Education and Training (GET) band which includes Grade R to 9 (ages 6 to 15) and the Further Education and Training (FET) band which includes Grade 10-12 (ages 16 to 18 ). 


\section{Snapshot 1: 1990-1996 (Interim Core syllabus)}

In South Africa, history teaching during apartheid was mostly located in the traditional fact-learning tradition (Kros 1996; Morrell 1990), which emphasised rote learning of propositional knowledge. The content reflected a Eurocentric and Afrikaner nationalist perspective (du Preez, 1983). However, some schools within the white and Indian education departments offered a more progressive, enquiry-based history education. This was informed by the British Schools Council History Project, which focused on the procedural knowledge informing history as a discipline.

After the democratic government took power in 1994, it was necessary to create a single curriculum for the newly established national department of education, as there were nineteen different departments of education, as well as to rid the apartheid syllabus of any overly racist or sexist content (Kros, 1996). The Interim Core Syllabus (ICS) document was a result of the curriculum "cleansing" process (Jansen, 1999). It was an interim measure, while the planning for a more extensive curriculum reform could take place. The ICS of 1996 broadened the history narrative to move beyond 'White' history, adapted to the needs of a democratic order, and yet retained an essentially traditional approach to history teaching (DoE, 2000). Kros (1996) argues that these syllabuses were still fragmented and overloaded with content, and that they continued to tell the story of the elites with little social history (Seleti, 1997). The regulative discourse at this point reflects a shift from segregation to integration.

Both the progressive National Education Co-ordinating Committee and the state were thinking about an alternative history curriculum in the early 1990s. In the PRF, the History Education Group hosted three conferences which were attended by teachers and academics from a range of educational and political perspectives. The Wits History project were promoting a revisionist historiography and a People's History as a counter to the racist and elitist history propagated during apartheid (Krige, Taylor, \& Vadi, 1992; Callinicos, 1980). At the same time, the state appointed a committee from the Human Sciences Research Council to investigate the teaching of secondary school history in South Africa (van der Merwe, Vermaak, \& Lombard, 1991). Their illustrative syllabus was not well received by the History Education Group. In the end, the thinking of neither the apartheid state nor the progressive left influenced the first new curriculum, which took an outcomes-based approach. The discourse of 'people's education' 
and of history from below were subsumed by the official competence discourse in the late 1990s (Chisholm, 2004).

\section{Snapshot 2: 1997-2001 (Curriculum 2005)}

The first major post-apartheid shift in the curriculum was the radical outcomes-based curriculum called Curriculum 2005(C2005) for the primary school up to Grade 9 (Department of Education, 1997). The regulative discourse informing this were the imperatives for transformation, redress and access, for a symbolic break from Apartheid and the strong influence from labour for a competence-based curriculum that integrated education and training (Christie, 1997). History was integrated with geography into a learning area called Human and Social Sciences (HSS). The C2005 curriculum document had complex levels of specific outcomes, assessment criteria, range statement and performance indicators (See Table 2). The HSS learning area combined the concepts of time, space, relationships and change into nine learning outcomes, such as "Demonstrate a critical understanding of how South African society has changed and developed". Although the key history curriculum debates in the early 1990s had been about what content should be taught to counter the Afrikaans nationalism of the apartheid curriculum, ironically there were no lists of content topics provided in the $\mathrm{C} 2005$ documents. Instead, broad sets of concepts which were labelled "range statements" were provided to indicate to teachers what they should teach, and there were "performance indicators" which described what learners should be able to do.

\section{Table 2: Excerpt from the C2005 Human and Social Sciences for Senior Phase (Grades 7-9)}

\begin{tabular}{|c|c|c|}
\hline \multicolumn{3}{|c|}{$\begin{array}{l}\text { Specific Outcome 1: Demonstrate a critical understanding of how South African } \\
\text { society has changed and developed }\end{array}$} \\
\hline $\begin{array}{l}\text { Assessment } \\
\text { criteria }\end{array}$ & RANGE STATEMENTS & $\begin{array}{l}\text { PERFORMANCE } \\
\text { INDICATORS }\end{array}$ \\
\hline $\begin{array}{l}\text { Key features } \\
\text { of change over } \\
\text { time and space } \\
\text { are critically } \\
\text { examined }\end{array}$ & $\begin{array}{l}\text { Key features to include: } \\
* \text { socio-economic relations } \\
\text { * Forms of state and power } \\
\text { relations }\end{array}$ & $\begin{array}{l}\text { * Explain how differ aspects of } \\
\text { past society were inter-related } \\
* \text { Give an account of the changes } \\
\text { experienced by communities, } \\
\text { including struggles over land, } \\
\text { resources and political rights }\end{array}$ \\
\hline
\end{tabular}




\begin{tabular}{|c|c|c|}
\hline $\begin{array}{l}\text { Key features of } \\
\text { change over time } \\
\text { and space are } \\
\text { critically examined } \\
\text { (continues...) }\end{array}$ & $\begin{array}{l}\text { * Forms of social } \\
\text { organisation [e.g. hunter } \\
\text { gatherer, herder, farming, } \\
\text { colonial (including slavery), } \\
\text { industrial } \\
\text { * ideologies and belief } \\
\text { systems } \\
\text { * levels of inequality (e.g. } \\
\text { social class, individual } \\
\text { circumstances } \\
\text { * period: } \\
\text { pre-colonial (from earliest } \\
\text { hominids). Colonial, post } \\
\text { colonial Apartheid, post- } \\
\text { Apartheid } \\
\text { Processes of change to } \\
\text { include: } \\
\text { * dispossession } \\
\text { * repression } \\
* \text { resistance and struggle } \\
\text { * liberation }\end{array}$ & $\begin{array}{l}\text { * Analyse the impact of } \\
\text { imperialism and nationalism on } \\
\text { different classes in South Africa } \\
\text { over time } \\
\text { * Identify key stages in the } \\
\text { development of African } \\
\text { nationalism and the struggle for } \\
\text { liberation and decolonisation in } \\
\text { Southern Africa. }\end{array}$ \\
\hline
\end{tabular}

Source: Department of Education, 1997:5.

The range statements in Table 2 shows that the historiography underpinning the instructional discourse was a radical one, with a strong desire for learners to understand inequality, struggles for land, resources, for decolonisation and liberation. This signified a complete break from the intention of the apartheid curriculum history curriculum. However, these concepts were not sequenced in a conceptually coherent way that created a logical narrative which could be easily learned. Since the concepts were not organised or sequenced chronologically nor thematically, it is unsurprising that teachers or learners did not know how to make sense of them.

The concepts such as imperialism, decolonisation and nationalism indicate that specialised substantive history knowledge was presented at a very abstract level. Regarding procedural knowledge, the HSS learning area had one specific outcome which focused on the requirement for learners to "Demonstrate the ability to use a range of skills and techniques in the HSS context". The policy envisioned that learners should learn from a range of 
sources, particularly oral sources, archaeological sources and sources of material culture, as well as documents, maps and statistical sources. Thus, the procedural knowledge was specialised to history as a discipline, such as identifying bias and explaining how sources may be used to create an account of an event or process. However, the focus on sources does not embrace the full range of second order concepts, which include identifying continuity and change, cause and effect, understanding the moral aspect of historical interpretations and taking an historical perspective (Seixas, 2017). The rationale for the HSS learning area was that it should contribute "to developing responsible citizens in a culturally diverse, democratic society within an interdependent world". This seems to indicate that the curriculum wished to promote the development of global citizens, and there was not a focus on nationalistic history. The discourse of C2005 makes it clear that the purpose of this curriculum was the development of generic outcomes and not of disciplinary thinking.

The Human and Social Sciences curriculum was written by a Learning Area Committee (LAC) which represented various stakeholders. This included the department of education, teacher unions, NGOs, professional associations and academics (Siebörger 1997; Seleti 1997). Thus, it was made up of actors in both the Official Recontextualising Field (department of education officials) and the Pedagogic Recontextualising Field, although officials from the national and provincial departments still had the greatest representation, and greater power to determine the structure of the curriculum. The committee was expected to identify the learning outcomes for the new integrated learning area, constrained by tight time frames and lack of clarity about exactly what was expected. These processes were terribly unwieldy as many "stakeholders" lacked expertise in curriculum development processes and they had insufficient time to consult with their constituencies (Fataar 1999; Siebörger 1997). In the end, a small Technical Committee representing the ORF was set the task of rationalizing and organizing all the work produced by the LACs.

Curriculum 2005 was short lived and was not implemented beyond the early grades. At a practical level, the curriculum was implemented too quickly, as it was rolled out in Grade 1 in 1998, after only being released in mid-1997. There was not enough time to train teachers and to develop materials. The radical outcomes-based design vastly under-estimated teachers' ability to develop their own resources and engage with a curriculum that did not clearly specify content as well as the vast differences in school context which exist 
in South Africa (Jansen, 1999a). Despite the challenges, many teachers and teacher educators embraced its ideology as the transformational panacea of the authoritarian apartheid curriculum. The state did not welcome critiques of OBE, such as Jansen's (1999b).

A new Minister of Education in 1999 opened up the space for a review of the curriculum. Prof Kader Asmal established a review committee to review C2005 in February 2000. In addition to the practical implementation problems of teacher development and lack of resources, the Committee found that the curriculum design was under-specified in terms of content and progression, and that there was little alignment between curriculum and assessment policy (Department of Education, 2000b). Their Report recommended that the curriculum be revised and streamlined in order to promote integration and conceptual coherence.

Fataar (2006) argues that the review of C2005 was dominated by an academic policy network which was drawn from the Education Faculties of liberal English- speaking universities, and in particular a subgroup who used Bernstein's distinction between hierarchical and vertical knowledge structures as a key conceptual critique of C2005. This was an example of actors in the PRF having an effect on the official pedagogic discourse, as the Review committee critiqued C2005 for its focus everyday knowledge at the expense of formal school knowledge (Department of Education, 2000b).

Kader Asmal's tenure as Minister of Education began a distinct movement at the regulative level of the ORF to reinsert history more strongly into the school curriculum, primarily because he supported the teaching of history and the humanities (Chisholm, 2004). At the same time as the C2005 Review Committee was working (February - May 2000), Minister Asmal assembled a group of diverse thinkers to form a Working Group which wrote a report entitled Values, education and democracy. This report called for the establishment of a panel of historians and archaeologists to advise the Minister on how best to strengthen the teaching of history in South African schools. In response, Asmal launched the History and Archaeology Panel and the Values in Education Initiative on 12 September 2000 which was required to undertake a critical analysis of the teaching of history and evolution in schools, the state of teacher training and the quality of support materials, and to make recommendations on how to strengthen these three areas. 
Both the History and Archaeology Panel (Department of Education, 2000a). and the Review of Curriculum 2005 recommended that the subjects of History and Geography should be taught separately within the Social Sciences Learning Area. In addition, history content needed to be specified for teachers because the neglect of content meant that the ideology of apartheid may not be challenged at all, and that teachers would simply continue teach what they knew best (Chisholm, 2004).

The movement to reinsert history into the curriculum did not go unchallenged and there were continuing debates about whether history should have its own space in the curriculum at all. One reason is that many black adults schooled during apartheid associated school history with a rote learning and authoritarian approach that supported their oppression and subjugation (Wassermann, 2017). However, Asmal supported the importance of teaching of history which "should ensure learners develop a narrative and conceptual understanding of the history of South Africa and Africa, and their place in the world" (Department of Education, 2000a: 138). Further support of this position was a report called the Manifesto on values, education, and democracy, which outlines sixteen strategies for instilling democratic values in young South Africans. The manifesto states:

Putting history back into the curriculum is a means of nurturing critical inquiry and forming an historical consciousness. A critical knowledge of history it argues, is essential in building the dignity of human values within an informed awareness of the past, preventing amnesia, checking triumphalism, opposing a manipulative or instrumental use of the past, and providing a buffer against the 'dumbing down' of the citizenry (James, 2001: vi).

Here the purpose of learning history is understood as nurturing critical thinking and developing historical consciousness, which is essentially a disciplinary focus, and not a patriotic one. In the same month that the Manifesto was published (August 2001), the Minister launched the South African History Project (SAHP). In his opening speech, Prof Asmal argued that history is vital for reminding us that any future should be based on a sound awareness of the role of the past. He said that the role of the SAHP was to promote and enhance the conditions and status of the learning and teaching of history in the South African schooling system, with the goal of restoring its material position and intellectual purchase in the classroom by engaging with processes of curriculum development and reviewing, revising and rewriting textbooks (Asmal, 2001). 
These developments show that the official regulative discourse began to foreground the importance of school history which Curriculum 2005 had underplayed (Wassermann, 2017). This new discourse emphasised that the purpose of school history should be to develop an 'informed' view of the past and not a manipulative or "instrumental" view. The discourse supported a disciplinary view of history which was evident in the revised curriculum which replaced C2005.

\section{Snapshot 3: 2002-2009 (National Curriculum Statements)}

This renewed support for history meant that when the Revised National Curriculum Statements (RNCS) for Grade R to 9 was released in 2002, History and Geography were presented as distinct subjects with their own learning outcomes and content, although they were still part of the Social Science learning area (Department of Education, 2002). History had its own learning outcomes which promoted "enquiry skills to investigate the past and present, historical knowledge and understanding and historical interpretation skills" (Department of Education, 2002: 5). This curriculum was still outcomes-based, in that it set the outcomes and assessment standards to be achieved and encouraged a learner-centred and activitybased approach to education. However, the curriculum document also included a chapter which outlined the 'knowledge focus' for history for each grade. The curriculum document states that content and assessment standards are closely linked, and that standards can only be demonstrated in terms of the content.

Table 3: Revised National Curriculum Statements (Social Science) History Knowledge focus for Grade 6, 7 and 8

\begin{tabular}{|l|l|l|}
\hline Grade 6 & Grade 7 & Grade 8 \\
\hline $\begin{array}{l}\text { Organisation of African } \\
\text { societies (kingdoms of } \\
\text { Southern Africa) }\end{array}$ & $\begin{array}{l}\text { Human evolution } \\
\text { (early hominid } \\
\text { discovered in South and } \\
\text { East Africa) }\end{array}$ & $\begin{array}{l}\text { Changing Worlds: the French } \\
\text { Revolution }\end{array}$ \\
\hline $\begin{array}{l}\text { Exploration and } \\
\text { exploitation from the } \\
\text { fourteenth century } \\
\text { onwards (maps of } \\
\begin{array}{l}\text { Africa, science and } \\
\text { technology) }\end{array}\end{array}$ & $\begin{array}{l}\text { Early trading systems } \\
\text { (from the ninth to the } \\
\text { nineteenth centuries, } \\
\text { including Arab trade, } \\
\text { East Africa, Great } \\
\text { Zimbabwe, trans- } \\
\text { Saharan trade) }\end{array}$ & $\begin{array}{l}\text { Changing Worlds: } \\
\text { Industrialisation } \\
\text { Industrial Revolution in Britain } \\
\text { Industrialisation in South } \\
\text { Africa (mining, land and cities) }\end{array}$ \\
\hline
\end{tabular}




\begin{tabular}{|l|l|l|}
\hline $\begin{array}{l}\text { The history of medicine } \\
\text { (medical discoveries, } \\
\text { indigenous medicine and } \\
\text { traditional healing) }\end{array}$ & $\begin{array}{l}\text { Moving frontiers } \\
\text { (contact, conflict and } \\
\text { dispossession in the } \\
\text { Eastern Cape and } \\
\text { USA in the nineteenth } \\
\text { century) }\end{array}$ & $\begin{array}{l}\text { Resisting British Control } \\
\text { (could include Zulu-British } \\
\text { wars, Pedi-British) } \\
\text { South African War }\end{array}$ \\
\hline $\begin{array}{l}\text { Democracy in South } \\
\text { Africa (what is } \\
\text { democracy, national } \\
\text { symbols) }\end{array}$ & $\begin{array}{l}\text { Systems of democracy } \\
\text { (the American } \\
\text { Revolution) }\end{array}$ & $\begin{array}{l}\text { Experience of colonialism in } \\
\text { the nineteenth and twentieth } \\
\text { century }\end{array}$ \\
\hline & & $\begin{array}{l}\text { Changing ideas and } \\
\text { technologies: World War I }\end{array}$ \\
\hline
\end{tabular}

Source: Department of Education 2002:89.

The instructional discourse shows that the selection of knowledge (Table 3 ) is quite different to the C2005 Senior Phase (as seen in Table 2), as the space and time frames of particular topics are now made clearer. The curriculum is organised using universal concepts such as exploration and exploitation, early trading systems, industrialisation and systems of democracy, which are exemplified by either South African or international events. In the Senior Phase, "learners should be able to place events, people and changes in the periods studied within a chronological framework" (59) although it is not clear that chronology and context of events are emphasised in the knowledge focus (see Table 3). The radical historiography reflected in the Senior Phase curriculum of C2005 was replaced by a discourse that supports human rights, Constitutional values, learner agency and the promotion of critical thinking around the reliability of sources and different interpretations of history. One purpose of the Social Sciences learning area was "to develop an awareness of how we can influence our future by confronting and challenging economic and social inequality to build a non-racial, democratic future and present" (Department of Education, 2002:4). 
Image 1: Excerpt from a Standard 4 History textbook (1983) and a Grade 6 Social Science textbook (2009)
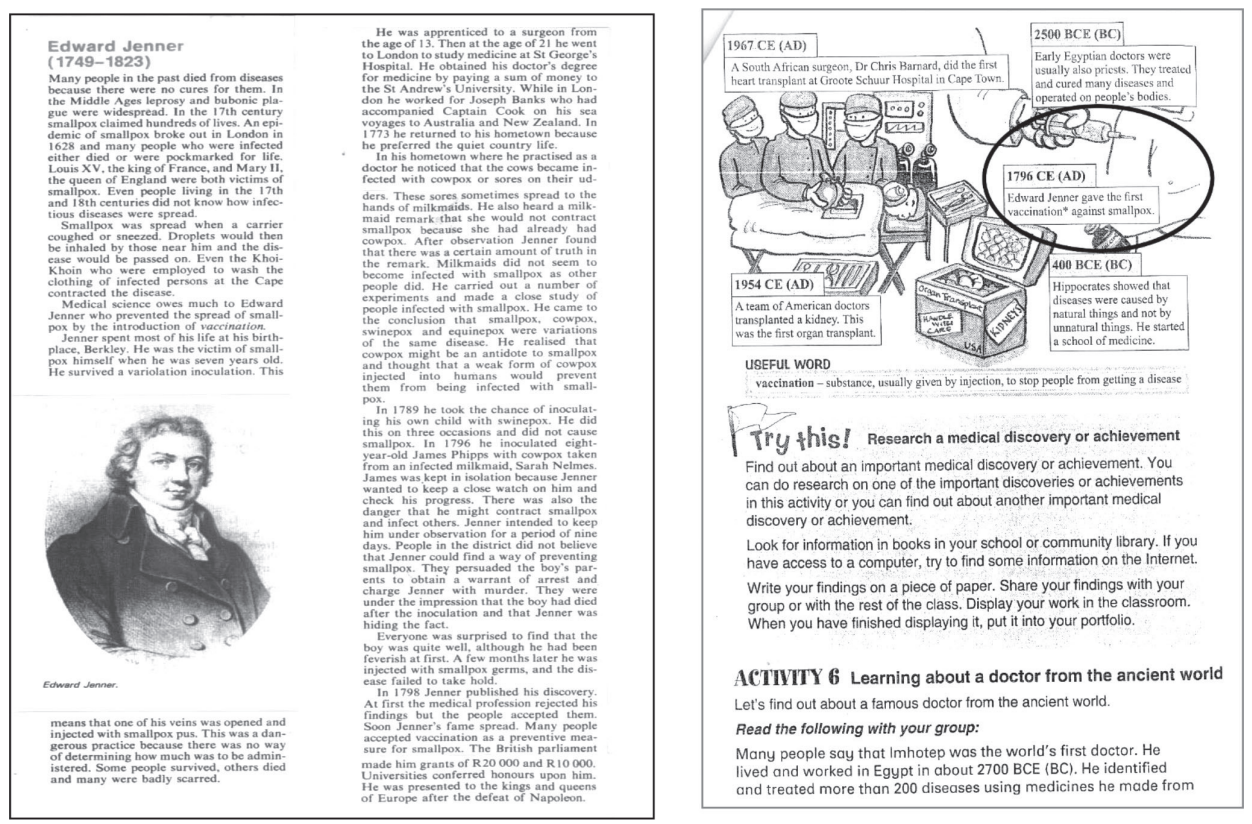

Source: C Bertram and P Bharath, Specialised knowledge and everyday knowledge in old and new Grade 6 history textbooks, Education as Change, 15(1), 2011, pp. 63-80.

Although there was a strengthening of substantive knowledge in the NCS when compared to $\mathrm{C} 2005$, it was still an outcomes-based curriculum, which meant that learning outcomes were the organizing principle of the sequencing and assessment of knowledge. The implications for history textbooks (particularly in the primary school) meant that the organizing principle of chronological narrative was replaced by smaller fragments of knowledge. Learner activities were foregrounded as the official discourse of learner-centred education and the active learner was most often interpreted to mean lots of classroom activities. This can be seen starkly in Figure 1, which shows a page from a 1983 Standard 4 (now Grade 6) textbook, which carries a text-based narrative about Jenner's discovery of a smallpox vaccine, and a page from a 2009 Grade 6 textbook on the topic "History of medicine". The latter has small chunks of text and many activities (Bertram \& Bharath, 2011).

A year after the revised curriculum was released for Grades R-9, the process started for designing the history curriculum for the senior secondary phase of schooling (Grades 10-12). The History Working group which designed 
the curriculum comprised three representatives of the South African History Project, and three department of education representatives. It was taken for granted that outcomes would lead the process of curriculum development and it was clear that the curriculum should adhere to the principles of social justice, promoting indigenous knowledge as well as the Constitutional values of non-sexism and non-racism.

The NCS history curriculum (Department of Education, 2003) for Grade 10 - 12 replaced the Interim Core Syllabus of 1996, as C2005 had only been developed for Grades 0-9 (General Education and Training band). While the ICS had two distinct sections of South African and General history, the NCS took a more integrated approach to knowledge which used key questions to frame and structure the knowledge, with a focus on broad themes. The NCS states

The overall key questions for the FET band are: How do we understand our world today? What legacies of the past shape the present? In understanding our world today and legacies that shaped our present, the broad themes of power alignments, human rights issues, of civil society and globalisation were used in suggesting areas of content (Department of Education, 2003: 24) (my italics).

For example, the French Revolution is taught as an exemplar (along with the American War of Independence) of the universal concept "quest for liberty". Thus, the instructional discourse shows that universal concepts order the curriculum and provide an organisational frame, rather than chronology (Bertram 2016). The NCS shifts away from a strong Eurocentric and South African focus to place emphasis on the world with the overall key question being 'How do we understand our world today?' The Grade 10 proposed content opens with the question 'What was the world like in the mid-fifteenth century?' and examples provided are Africa (Songhay), China (Ming), India (Mogul), Ottoman Empire, the Americas.

The purpose of school history in the NCS is "to build the capacity of people to make informed choices in order to contribute constructively to society and to advance democracy" (my italics) and to develop "a rigorous process of historical enquiry, as well as being a vehicle to support democracy and human rights" (Department of Education, 2003: 9). However, studies of textbooks (Chisholm, 2008; Bertram \& Bharath, 2011) suggested that this rigorous historical enquiry was not likely to be achieved in all classrooms, as some textbooks showed little evidence of history enquiry nor sufficient substantive 
knowledge to develop learners' understanding of chronology and narrative.

These National Curriculum Statements were used in primary schools from 2004, and from 2006 in the FET band. It was at this time that the results of the 2003 Trends in International Mathematics and Science Study (TIMSS) were released which showed that South African Grade 8 learners performed the lowest of all the 50 countries which participated in the study (Reddy, 2006). In response, many argued that a key cause of poor achievement was the unstructured nature of the outcomes-based curriculum, which did not provide sufficient clarity for teachers regarding assessment and content, particularly in the first years of primary school.

\section{Snapshot 4: 2009-2015 (Curriculum and Assessment Policy Statements)}

In 2009, the new Minister of Basic Education, Ms Angie Motshekga appointed a Ministerial Review Committee to review the implementation of the National Curriculum Statements and to make recommendations for strengthening its implementation. The team consisted of two 'overseeing' bureaucrats, two members of the two largest teacher unions, three academics and a publisher (Hoadley, 2018). Thus actors from both the ORF and PRF were present. The committee held hearings in each of the provinces with teachers and other stakeholders to understand their experiences of implementing the NCS. One issue that emerged was that there were a number of different curriculum documents at local, provincial and national level that were fragmented, and often contradictory, which was confusing for teachers. It seemed that some teachers and departmental officials still embraced the enduring discourses of $\mathrm{C} 2005$, namely that textbooks should not be used, that teachers should develop their own learning resources, and that group work was a preferred teaching method. The Review Committee recommended that there should be only one main curriculum document for each subject and grade, which should be unambiguous, succinct and clearly specify "knowledge (content, concepts and skills) to be learnt, recommended texts, recommended pedagogical approaches and assessment requirements" (Department of Education, 2009:45). A major recommendation was that the design features of OBE, particularly learning outcomes and assessment standards, should not feature in the new Curriculum and Assessment Policy documents. Minister Motshekga then announced to parliament in October 2009 that "OBE was dead". 
The writing of these streamlined Curriculum and Assessment Policy Statements (CAPS) for each phase and subject began in 2010. The process was uneven and fraught with tension over who would do the rewriting, the tight timeframes and the lack of communication and leadership from the Department of Education (Hoadley, 2018). Mostly only one person per subject worked on this curriculum, in contrast to the more representative and collaborative process of $\mathrm{C} 2005$ and the NCS.

In terms of the instructional discourse, the Ministerial Review Report (Department of Education, 2009) had invoked the importance of 'powerful knowledge' (Young, 2008). In the new CAPS history curriculum this meant that there was a "greater emphasis on narrative, historical concepts, interpretation, argumentation and justification" as well as multi-perspectivity (Chisholm, 2015). The CAPS documents for GET and FET state that their aim is to develop both citizenship and the skills of historical enquiry. The CAPS has a more detailed description of historical concepts than the NCS, and describes the following second-order concepts as pertinent to the study of History: working with evidence; multi-perspectivity; cause and effect; change and continuity (which also relates to similarity and difference) and time and chronology. The focus on disciplinary procedural knowledge is strong, as is the detailed specification of what substantive knowledge should be covered in each topic. There is also detailed specification of what will be assessed in the final Grade 12 school leaving exam which comprises of source-based questions and essays.

Regarding the selection of knowledge, the CAPS curriculum aimed to strike a balance between South African, African and world history (see Table 4, which categorises the various topics according to the focus on South African, African and world history). Wassermann (2017: 64) argues that the NCS and CAPS history curriculum had created "a new official master narrative and hence a new official memory, based on an imagined new nationalism and identities. This was achieved by downplaying the true horrors of apartheid, attributing a messianic status to Mandela, foregrounding how South Africa became a democracy in 1994 under the ANC and presenting a neat history without any real villains, but clear heroes". His claim is supported by classroom-based research done in 2010 and 2011 in two Johannesburg schools (Teeger, 2015). The study shows how all teachers and Grade 9 learners discussed apartheid in a way that told "both sides of the story" in order to minimise conflict and guilt and downplay systemic oppression. Thus although the instructional discourse of the curriculum supported a range of 
perspectives and the importance of weighing up evidence and argument, the regulative discourse was one of nation-building.

At this time, the state established strong regulations regarding the writing and publishing of textbooks, which were only selected onto the official list if they matched the official curriculum exactly. In this way, the ORF established power over the PRF, and did not allow textbook writers any autonomy to interpret the official curriculum.

During this time, there was a growing focus on the measurement of learner achievement which was monitored by officials in the ORF. This regulative discourse of accountability and measurement of results lead to the strengthening of external regulation of teachers' work by requiring teachers to use Annual Teaching Plans which plot out how many teaching weeks should be allocated to each topic, and strong monitoring of schools' examination results (Msibi \& Mchunu, 2013).

\section{Snapshot 5: 2014-2019 (History Ministerial Task Team)}

The death of past president Nelson Mandela in December 2013, created a space where Mandela's commitment to reconciliation without redress could be critiqued. The xenophobic attacks on African migrants in 2008 and 2013 and growing social conflict and division seemed to indicate a fading 'rainbow nation'. These were partly explained by asserting that young South Africans did not know their history (Bambo et al. 2017; Davids 2016). There was also a growing discourse calling for the decolonisation of the curriculum with the \#Rhodesmustfall and \#Feesmustfall protests on university campuses which started in 2015 .

A discourse emerged that echoed a lament common in many countries (vanSledright, 2008), namely that the youth did not know their history (Wassermann, 2017). The South African Democratic Teachers Union ${ }^{2}$ (SADTU) put out a document explaining that history should become compulsory so that it could "provide a foundation of a much needed celebration of our past" (South African Democratic Teachers Union, no date) and "introduce learners to traditions, practices, values and norms of the group". This was not only a call to make history compulsory, but also to change the story that was currently told in schools. The document states that "history needs to tell a correct story that South Africa was not discovered by white settlers in $1652 \ldots$ but that our people were already

2 SADTU is the biggest teacher union in South Africa, comprising approximately 260000 members. It part of the trade union federation which is an ally of the ruling African National Congress (ANC). 
trading in diamond and gold before this land was stolen through blood baths" (5). It assumes that there is a 'correct' story that should be told, which reflects a memory history approach, rather than the disciplinary history of multi-perspectives that is currently supported in the CAPS. Tosh (2006) uses the term social memory and Lévesque (2008) uses the term Memory-history to describe history which is about commemoration, memory and heritage. It is often used to support a particular version of a national history where history is about believing a national narrative and not about analytic disciplinary enquiry.

Under political pressure to act on the perception that "our young people do not appreciate our country's history and that of the African continent" (Ndlovu et al. 2018: 8), Minister of Basic Education, Angie Motshekga appointed a History Ministerial Task Team in June 2015. Its brief was to conduct research into how to best implement the introduction of compulsory history in Grade 10-12 as part of the citizenship component of the subject Life Orientation ${ }^{3}$. The team comprised primarily academic historians and only one history educator, which seems odd given that the task was to engage with the school history curriculum.

The Ministerial task team presented their report in 2018 with the recommendations that history should be made compulsory in the FET phase, and that the history curriculum should be re-written (Ndlovu et al. 2018). The task team noted that while there were topics on Africa in the curriculum, these were not addressed substantially at the higher grades. The report also argued that CAPS does not support human solidarity or Ubuntu, does not sufficiently focus on African nationalism, does not teach archaeology or oral traditions in a systematic way and supports a liberal historiography. The report argues that the gaze of history continues towards Europe and that the South African content avoids problematic and controversial issues "which undermines the fact that a multi-perspective approach is relevant" (Ndlovu et al. 2018: 41). In fact the CAPS aims to develop both citizenship and a disciplinary perspective, which includes multi-perspectives and engagement with a range of sources and a range of different interpretations.

In her speech at the launch of this report, Minister Motshekga supported this recommendation to re-write the history curriculum and suggested that the purpose of the recalibrated history curriculum must be the

3 Life Orientation is a compulsory subject for all learners up to Grade 12 that covers life skills, career guidance and citizenship. 
'decolonisation of the African mind' (Motshekga, 2018). She went on to say that "History should, by design, enable learners to be active citizens including able to engage critically with the truths of colonialism, apartheid and the liberation struggle. Young people should be empowered with values, attitudes and behaviours that contribute to nation-building, social cohesion and national reconciliation". These purposes are not in conflict with the purposes of the current CAPS curriculum, although CAPS has a stronger focus on developing historical thinking than on nation-building.

History educators (actors in the PRF and field of reproduction) were less excited about the proposal to make school history compulsory, noting that the country does not have the resources, nor qualified teachers to do this (Chisholm 2018; Bailey 2018) and questioned the quality of the research which was presented in the MTT report (van Eeden and Warnich, 2018). There is no evidence that learners would welcome the proposal for history to be made compulsory. A recent study of high school learners in rural KwaZulu-Natal suggests that they choose not to study history because it will not provide them with access to the city and a job (Wassermann, Maposa \& Mhlongo, 2018). This indicates that learners may not be keen on taking compulsory history until Grade 12 , indicating a tension between the utilitarian purposes of schooling and the socialisation purposes supported by the state, namely nation-building, social cohesion and national reconciliation.

The Grade 12 examination results indicate that if history were made compulsory, many learners would not perform well in the history exams. In 2018, history students accounted for 32\% (154 536) of the total Grade 12 learners who wrote the National Senior Certificate examination (Department of Basic Education, 2019). The diagnostic report shows that many candidates are unable to answer higher order questions on sources nor to order their knowledge into coherent argument when writing an essay.

Thus there is a tension between academics and teachers in the PRF who argue cogently why history should not be made compulsory (Ndlovu, Malinga, Bailey, 2019) and academic historians on the MTT who represent the ORF. This tension has been explained by the notion that the proposal is a political rather than a pedagogic one (Davids, 2016). The regulative discourse of the MTT report reflects the prevailing decolonising discourses in South African education (Le Grange, 2016). For example, the chairperson of the MTT argues that gender history linked to precolonial history should 
be included in the school curriculum to counteract the "epistemological genocide" committed by CAPS regarding the teaching about African women (Ndlovu, Malinga, Bailey, 2019).

It will be interesting to see how the MTT which has been tasked to revise the history curriculum will select history knowledge and how it resolve the tensions between the purposes of disciplinary history, memory history and history for democratic citizenship, within the prevailing decolonial discourse.

\section{Conclusion}

This article has described how the instructional discourses of the history curriculum have shifted over the past 25 years, sometimes in tandem with, and sometimes in tension with the prevailing regulative discourses. Generally actors in the Official Recontextualising Field (ORF) have had the final say in which knowledge has been selected and assessed. For example, while actors in the PRF had imagined a people's history post1994, the competency discourses of outcomes-based education meant that C2005 evaded the selection of content knowledge and focused on learning outcomes. Subsequently, the NCS and the CAPS selected specialized procedural and substantive knowledge which covered a wide range of contexts and topics. The focus on the disciplinary aspects of history, as well as the state's obsession with measuring learner achievement, seemed to background the socialization purpose of school history for citizenship. In the past five years, decolonial discourses have highlighted the regulative purposes of school history, and supported a new curriculum which should 'contribute to nation-building, social cohesion and national reconciliation' (Motshekga, 2018). 


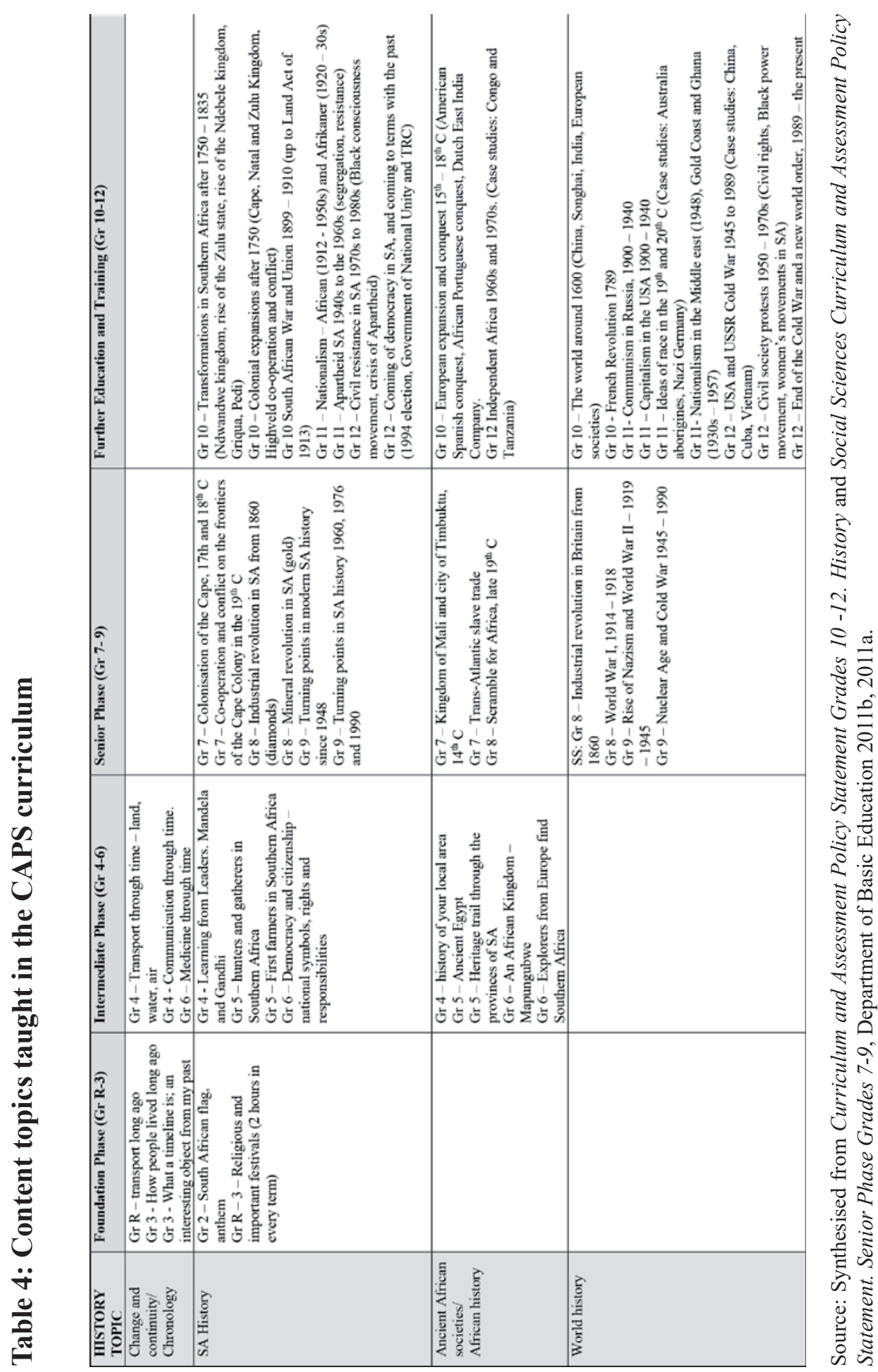




\section{References}

Asmal, K 2001. Speech: Launch of the South African History project. Available at: http://www. info.gov.za/speeches/2001/0108281145a1002.htm, Accessed 30 July 2005.

Bailey, M 2018. The History Ministerial Task team fails to explain why compulsory matric history is necessary. The Daily Maverick, 19 September 2018.

Ball, SJ 2006. Education policy and social class. The selected works of Stephen J. Ball. Routledge: London and New York.

Bambo, N, Chisholm, L, Friedman, M, Sindoh AQ 2017. Decolonising the teacher education curriculum: Mapping the status and nature of teaching and learning of history in faculties and schools of education in South Africa. Johannesburg: University of Johannesburg and University of the Witwatersrand.

Bernstein, B 1996. Pedagogy, symbolic control and identity. Theory, research, critique. Taylor \& Francis: London.

Bernstein, B 2000. Pedagogy, symbolic control and identity: theory, research and critique (revised edition). Rowman and Littlefield: Lanham.

Bernstein, B, Solomon, J 1999. Pedagogy, identity and the construction of a theory of symbolic control: Basil Bernstein questioned by Joseph Solomon. British Journal of Sociology of Education, 20:265-279.

Bertram, C 2009. Procedural and substantive knowledge: Some implications of an outcomes-based history curriculum in South Africa. Southern African Review of Education, 15(1):45-62.

Bertram, C 2012. Exploring an historical gaze: A language of description for the practice of school history. Journal of Curriculum Studies, 44(3):429-442.

Bertram, C 2016. Recontextualising principles for the selection, sequencing and progression of history knowledge in four school curricula. Journal of Education, 60:27-54.

Bertram, C, \& Bharath, P 2011. Specialised knowledge and everyday knowledge in old and new Grade 6 history textbooks. Education as Change, 15(1):63-80.

Callinicos, L 1980. Gold and workers 1886-1924. A people's history of South Africa, Volume one. Raven Press: Johannesburg. 
Chisholm, L 2004. The history curriculum in the (revised) national curriculum statement: an introduction. In: S Jeppie (ed.), Toward new histories for South Africa: On the place of our past in our present. Juta: Cape Town.

Chisholm, L 2005. The making of South Africa's National Curriculum Statement. Journal of Curriculum Studies, 37:193-208.

Chisholm, L 2008. Migration, citizenship and South African History textbooks. South African Historical Journal, 60:352-74.

Chisholm, L 2015. Curriculum transition in Germany and South Africa: 1990-2010. Comparative Education, 51:401-418.

Chisholm, L 2018. South Africa wants to make history compulsory at school. But can it? The Conversation, 1 June 2018.

Christie, P 1997. Global trends in local contexts: A South African perspective on competence debates. Discourse: Studies in the cultural politics of education, 18:55-69.

Davids, MN 2016. Making history compulsory: Politically inspired or pedagogically justified? Yesterday \& Today, 15:84-102.

Department of Basic Education. 2011a. Curriculum and Assessment Policy Statement Grades 10-12. Life Sciences. Department of Basic Education: Pretoria.

Department of Basic Education 2011b. Social Sciences Curriculum and Assessment Policy Statement. Senior Phase Grades 7-9. Government Printers: Pretoria.

Department of Basic Education 2019. National Senior Certificate 2018. Diagnostic Report Part 1. Pretoria: Department of Basic Education.

Department of Education 1997. Curriculum 2005 Lifelong learning for the 21st century. Pretoria: National Department of Education.

Department of Education 2000a. Report of the History and Archaeology Panel to the Minister of Education. Department of Education: Pretoria.

Department of Education 2000b. A South African curriculum for the twenty-first century: Report of the Review Committee on Curriculum 2005. Department of Education: Pretoria.

Department of Education 2002. C2005, Revised National Curriculum Statement Grades R-9 (Schools) Policy. Social Sciences. Department of Education: Pretoria. 
Department of Education 2003. National Curriculum Statement Grades 10 -12 (General) History Department of Education: Pretoria.

Department of Education 2009. Report of the Task Team for the Review of the Implementation of the National Curriculum Statement. Final Report. Presented to the Minister of Education, Ms. Angela Motshekga. Department of Education: Pretoria.

Du Preez, JM 1983. Africana Afrikaner: Master symbols in South African school textbooks. Librarius: Johannesburg.

Ensor, P 2004. Legitimating school knowledge: The pedagogic device and the remaking of the South African school-leaving certificate 1994-2004. Paper presented at the Third Basil Bernstein Symposium, University of Cambridge, July 2004.

Fataar, A 1999. Localisation, globalisation and compensatory legitimation: School curriculum policy and politics in South Africa. In: Comparative and International Education Conference proceedings. OISE, University of Toronto, Canada, 14-18 April 1999.

Guyver, R 2013. Editorial. History teaching, pedagogy, curriculum and politics: Dialogues and debates in regional, national, transnational, international and supranational settings. International Journal of Historical Learning, Teaching and Research, 11:3-10.

Hoadley, U 2018. Pedagogy in poverty. Lessons from twenty years of curriculum reform in South Africa. Routledge: London and New York.

Jacklin, H 2004. Repetition and difference: A rhythmanalysis of pedagogic practice, $\mathrm{PhD}$, University of Witwatersrand.

James, W (ed.) 2001. Manifesto on values, education and democracy. Department of Education: Cape Town.

Jansen, JD 1999a. A very noisy OBE': The implementation of OBE in Grade 1 classrooms. In JD Jansen, P Christie (eds.), Changing curriculum: Studies on outcomesbased education in South Africa. Juta \& Co Ltd.: Cape Town.

Jansen, JD 1999b. Why outcomes-based education will fail: An elaboration. In: JD Jansen, P Christie (eds.), Changing curriculum: Studies on outcomes-based education in South Africa. Juta \& Co Ltd.: Cape Town.

Krige, S, Taylor, N, Vadi, I 1992. History for the future: Taking another look at "What is history?". University of the Witwatersrand, Johannesburg: Education Policy Unit. 
Kros, C 1996. Trusting to the process - reflections on the flaws in the negotiating of the history curriculum in South Africa. Report No. 1. University of Witwatersrand, Johannesburg: The History Curriculum Research Project of Cambridge University Press and History Workshop.

Lamnias, C 2002. The contemporary pedagogic device: Functional impositions and limitations. Pedagogy, culture and society, 10:21-38.

Le Grange, L 2016. Decolonising the university curriculum. South African Journal of Higher Education, 30:1-12.

Lee, PJ 2004. Understanding history. In: P. Seixas (ed.), Theorizing historical consciousness. University of Toronto Press: Toronto.

Lee, PJ, and Ashby, R 2000. Progression in historical understanding among students ages 7 - 14. In: P Seixas, PN Stearns and S Wineburg (eds.), Teaching, learning and knowing history. New York University Press: New York.

Levesque, S 2008. Thinking historically: Educating students for the twenty-first century. University of Toronto Press: Toronto.

Morrell, R 1990. History textbooks and history teaching in South Africa: Present and future. In: Kenton Education Association Conference Proceedings. Port St. Johns.

Motshekga, A 2018. Minister Angie Motshekga approves re-appointment of the History Ministerial Task Team. South African Government: Pretoria.

Msibi, T, Mchunu, S 2013. The knot of curriculum and teacher professionalism in postapartheid South Africa. Education as Change, 17:19-35.

Ndlovu, SM, Lekgoathi, SP, Esterhuysen, A, Mkhize, NN, Weldon, G, Callinicos, L, Sithole, J 2018. Report of the History Ministerial Task Team for the Department of Basic Education. Department of Basic Education: Pretoria.

Ndlovu, SM, Malinga M \& Bailey, M 2019. Teaching History in Schools: Captured Curriculum/Political Pedagogy? South African Historical Journal, 71:2, 335345, DOI: $10.1080 / 02582473.2019 .1665886$.

Reddy, V 2006. Mathematics and science achievement at South African schools in TIMSS 2003. HSRC Press: Cape Town.

Schwab, JJ 1978. Education and the structure of the disciplines. In: I Westbury, NJ Wilkof (eds.) Science, curriculum and liberal education. University of Chicago Press: Chicago. 
Seixas, P 2017. A model of historical thinking. Educational Philosophy and Theory, 49:593-605.

Seleti, Y 1997. From history to human and social sciences: The new curriculum framework and the end of history for the general education and training level. Education Policy Unit Working Paper, 14.

Siebörger, R 1997. How the outcomes came out: A personal account and reflection on the initial processes of development of Curriculum 2005. In: Kenton Education Association, Kenton-at-the-gap conference proceedings. Hermanus, 31 October-1 November 1997.

Singh, P 2002. Pedagogising knowledge: Bernstein's theory of the pedagogic device. British Journal of Sociology of Education, 23:571-582.

South African Democratic Teachers Union no date. The importance of Teaching History as a Compulsory Subject.

Teeger, C 2015. Both sides of the story: History education in post-apartheid South Africa. American Sociological Review, 80(6):1175-1200.

Tosh, J 2006. The pursuit of history. Aims, methods and new directions in the study of modern history. Pearson Longman: Harlow.

Van der Merwe, A, Vermaak, A, Lombard, S 1991. An empirical investigation into the teaching of History in the RSA. HSRC Education Research Programme, 19. Human Sciences Research Council: Pretoria.

Van Eeden, ES, Warnich P 2018. Reflecting on the 2018 History Ministerial Task Team report on compulsory history in South Africa. Yesterday \& Today, 20:18-45.

Van Sledright, B 2008. Narratives of nation-state, historical knowledge and school history education. Review of Research in Education, 32:109-146.

Wassermann, J 2017. The state and volving of teaching about apartheid in school history in South Africa, circa 1994-2016. In: T Epstein and CL Peck (eds.), Teaching and learning difficult histories in international contexts. A critical socio cultural approach. Routledge: London and New York.

Wassermann, J, Maposa, M, Mhlongo, D 2018. If I choose history it is likely that I won't be able to leave for the cities to get a job - rural South African learners and the choosing of history as a subject. Journal of Education, 73:55-68.

Wertsch, JV 2002. Voices of collective remembering. Cambridge University Press, Cambridge. 
_... The pedagogic device and shifting discourses in the South African school history curriculum, pp. 1-29

Young, MFD 2008. Bringing knowledge back in. From social constructivism to social realism in the sociology of education. Routledge: London and New York. 